\title{
Studies on the effect of $\mathrm{pH}$ on the sorption of $\mathrm{Al}^{3+}$ and $\mathrm{Cr}^{6+}$ Ions from aqueous solutions by Almond Tree (Terminalia catappa L.) Biomass
}

\author{
Enemose Edith A. and *Osakwe, S.A. \\ Department of Chemistry, Delta State University, P. M. B 1, Abraka, Delta State, Nigeria
}

\begin{abstract}
Environmental protection requires the use of natural products instead of chemicals to minimize pollution. This investigation studies the use of a non-useful plant material as naturally occurring biosorbents for the removal of cationic pollutants in wastewater. The effect of $\mathrm{pH}$ on the sorption of $\mathrm{Al}^{3+}$ and $\mathrm{Cr}^{6+}$ ion unto Terminalia catappa biomass was investigated. The experimental results have been analysed in terms of Langmuir and Freundlich isotherms. The data showed that the maximum $\mathrm{pH}$ ( $\mathrm{pH}$ max) for efficient sorption of $\mathrm{Al}^{3+}$ was $4.0(85.5 \mathrm{mg} / \mathrm{g})$ and for $\mathrm{Cr}^{6+} 2.0(82.6 \mathrm{mg} / \mathrm{g})$. Evaluation using Langmuir equation gave the monolayer sorption capacity as $1.12 \mathrm{mg} / \mathrm{g}$ and $2.67 \mathrm{mg} / \mathrm{g}$ as maximum $\mathrm{pH}$ for $\mathrm{Al}^{3+}$ and $\mathrm{Cr}^{6+}$ respectively. The thermodynamic assessment of the metal ion - Terminalia catappa L. biomass system indicates the feasibility and spontaneous nature of the process.
\end{abstract}

Keywords: adsorption, heavy metal removal, almond tree, phytoremediation, water treatment.

\section{Introduction}

The conventional technologies for effluent treatment are not economically feasible for small-scale industries prevalent in developing economies due to huge capital investment. It is therefore necessary to search for alternative adsorbents which are low cost, often naturally occurring products that have good sorbent properties and are of no value to people.

Heavy metals tend to reach the environment from a vast array of anthropogenic sources as well as natural geochemical processes and some of these anthropogenic sources include wastes from industries, markets, agriculture and domestic wastes [1]. The presence of $\mathrm{Al}^{3+}$ and $\mathrm{Cr}^{6+}$ and other heavy metals in the environment has become a major threat to plant, animal and human life due to their bio-accumulating tendency and toxicity [2] and therefore must be removed from municipal and industrial effluents before discharge. Resultantly, it is necessary that there are technologies for controlling the concentrations of these metals in aqueous emissions.

A range of products had been examined. Few of these include pillared clay [3], sago waste [4], cassava waste [5], banana pith [6], Medicago sativa [7], wilt cocoyam [8], and spagnum moss peat [9].

The adsorbent used in this study is almond tree biomass. The almond tree belongs to the family called combretaceae (Combretum family) and the botanical name is Terminalia catappa L. The tree (Terminalia catappa L.) has been known for its usefulness in the medical world. The use of the biomass as a biosorbent for trace metals in water and waste effluents is expected to solve environmental problems.

The equilibrium distribution of metal ions between the sorbent and the solution is important in determining the maximum sorption capacity. Two sorption models, (the Langmuir and Freundlich) were used to assess the different isotherms and their ability to correlate experimental data. The Langmuir equation was chosen for the estimation of maximum adsorption capacity corresponding to complete monolayer coverage on the biomass surface, while the Freundlich model was used to estimate the adsorption intensity of the sorbent towards the biomass. The major aim of the present work is to investigate the potential use of the biomass of almond tree (Terminalia catappa L.) as a novel biosorbent for the sorption of valuable and toxic metal ions from aqueous media.

This paper reports the effect of $\mathrm{pH}$ on the ability of the biomass of the almond tree (Terminalia catappa L.) to remove $\mathrm{Al}^{3+}$ and $\mathrm{Cr}^{6+}$ ions from single metal ion solutions. The effect of varying initial $\mathrm{pH}$ and equilibrium sorption on the potential ability of the Terminalia catappa L. in removing these two metal ions from solution was investigated.

\section{Materials and Methods}

Collection and preparation of sample (biosorbent): The almond tree (Terminalia Catappa L.) leaves were collected from Akarai-Etiti, Akarai-Obodo and Aboh in Ndokwa East Local Government Area of Delta State, Nigeria. The leaves were collected with clean polythene bags and then air-dried for one week under normal sunlight conditions. The dried leaves were initially crushed to smaller size with mortar and pestle and further 
ground using a food processor (Magimix Cuisine System 5000) to 90- $\mu \mathrm{m}$ size to obtain a fine biomass which was then stored in clean, air tight plastic container and ready for use.

Biosorbent activation: The purpose of activation is to increase the porosity and open more pores in the biomass. The finely divided biomass was activated by soaking $5 \mathrm{~g}$ biomass in excess $0.03 \mathrm{M} \mathrm{HNO}_{3}$ for 25 hours, followed by washing thoroughly with deionized water. The washing process continued until the filtrate gave a negative EDTA (Ethylenediaminetetraacetic acid) test for heavy metal ions. The test was carried out by the addition of 5 drops of $0.001 \mathrm{M}$ EDTA solution and $2 \mathrm{ml}$ of $\mathrm{NH}_{3} / \mathrm{NH}_{4} \mathrm{Cl}$ buffer to $5 \mathrm{ml}$ of the washing water filtrate. The appearance of blue colour of the EDTA solution indicates the absence of metal ions. The filtered biomass was then oven-dried at $65^{\circ} \mathrm{C}$ to constant weight.

\section{Characterization of the Biomass}

The finely divided biomass was characterized for apparent density and porosity using mercury intrusion porosimeter (Micrometrics model-9310) and specific gravity bottle respectively. Pore volume was estimated as the inverse of reaction of particle density [8], while the ash content was determined using the ignition method by burning $1.0 \mathrm{~g}$ of biomass sample (placed in a thoroughly washed crucible) in a furnace which was pre-heated to $500^{\circ} \mathrm{C}$ for 3 hours. The crucible was removed and cooled in a desiccator and reweighed until a constant weight was obtained. The percentage ash content was calculated using the formula [8]:

$\% \operatorname{Ash}=\frac{\mathrm{M}_{\mathrm{a}}}{\mathrm{M}_{\mathrm{s}}} \times 100$

Where $M_{a}=$ mass of ash $(\mathrm{g})$ and $M_{s}=$ mass of sample used $(\mathrm{g})$.

\section{Preparation of Metal Solutions}

The aqueous solutions of the metal ions used were prepared by using analytical grade reagents provided by Fluka (Switzerland). Individual stock metal ion solution of $1000 \mathrm{mg} / \mathrm{l}$ concentration of $\mathrm{Al}^{\mathrm{III}}$ from $\mathrm{Al}\left(\mathrm{NO}_{3}\right)_{3} .9 \mathrm{H}_{2} \mathrm{O}$ and $\mathrm{Cr}^{\mathrm{VI}}$ from $\mathrm{K}_{2} \mathrm{Cr}_{2} \mathrm{O}_{7}$ were prepared. Serial dilutions were made with double distilled water from these stock solutions. In order to prevent the formation of metal hydroxide and allow all metal ions to be in solution, the stock solutions were acidified with $\mathrm{HNO}_{3}$ to $4<\mathrm{pH}<6$.

\section{Measurement}

pH was measured using X74081 Toptronic pH meter (Vetrerie ed Apparecchiature Per Laboratori Chmici, Milano, Italy). The metal ion concentrations were measured using Buck Scientific Atomic Absorption spectrophotometer (AAS model 300A, Germany). The analytical wavelengths used for the metals studied were: $309.3 \mathrm{~nm}$ and $358.2 \mathrm{~nm}$ for Aluminium and Chromium respectively. Analytical grade standards were used to calibrate the instrument response. The correlation coefficient for calibration curve was about 98.6.

The batch experiments were performed in duplicates and the mean (or the slope and intercept) was computed for each set of values.

\section{Experimental Procedure}

Adsorption isotherm studies

Effect of pH: The pH solutions ranging from 2.0 to 8.0 was studied. The solution were adjusted to the required $\mathrm{pH}$ values by adding a solution of $\mathrm{In} \mathrm{HCl}$ or $1 \mathrm{~m} \mathrm{NaOH}$. All the flasks were reacted on a shaker for one hour. The suspensions were filtered using No. 45 Whatman filter paper and then centrifuge at 2800rpm for five minutes in order to remove all traces of cloudiness. The metal ions investigated were determined using atomic absorption spectrophotometer (AAS model 300A.)

\section{Data Evaluation}

The amount of metal ion taken by the biomass was calculated using a mass balance equation which has been previously used by other researches in evaluating the amount of metal ion adsorbed by the Almond tree leaves biomass. The mass balanced equation is given as

$$
\mathrm{q}_{\mathrm{e}}=\frac{\mathrm{v}}{\mathrm{m}}\left(\mathrm{C}_{0}-\mathrm{C}_{\mathrm{e}}\right)
$$


where

$\mathrm{qe}=$ amount of metal ion removed by the almond tree waste biomass $(\mathrm{mg} / \mathrm{g}), \mathrm{m}=$ Mass of almond tree waste biomass used $(\mathrm{g}), \mathrm{v}=$ Volume of initial ion solution used $(\mathrm{ml})^{1} \mathrm{Co}=$ initial metal ion concentration $(\mathrm{mg} / \mathrm{l})$, $\mathrm{Ce}=$ Equilibrium metal ion concentration $(\mathrm{mg} / \mathrm{l})$.

\section{Adsorption Isotherms}

Two of the most sorption models were used to fit the experimental data. The Langmuir model which assumes that equilibrium is attained when a monolayer of the adsorbate molecules saturates the adsorbent. This model can be presented as in equation 3

$\mathrm{q}_{\mathrm{r}}=\frac{q_{m} K_{l} C_{e}}{1+K_{L} C_{e}}$

Where $X_{m}$ and $K$ are the Langmuir constants and specifically $\mathrm{Xm}$ is the monolayer and sorption capacity of the biomass $\mathrm{q}_{\mathrm{e}}$ is the concentration of metal ion on the biomass $\left(\mathrm{mg} / \mathrm{g}\right.$ ) at equilibrium and $\mathrm{C}_{\mathrm{e}}$ as the concentration (in $\mathrm{mg} / \mathrm{l})$ remaining in solution at equilibrium.

The linear form of the Langmuir model is given in equation 4

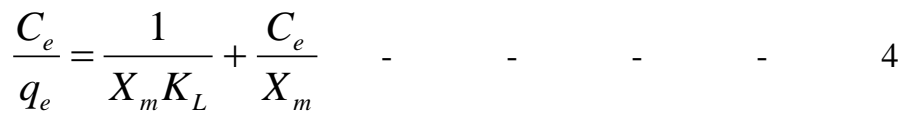

The capacity of the biomass can be obtained if a plot of $\mathrm{C}_{\mathrm{e}} / \mathrm{q}_{\mathrm{e}}$ against $\mathrm{C}_{\mathrm{e}}$ is made.

The second model is Fruendlich model which can be written as in equation 5 . The mathematical equation is given as:

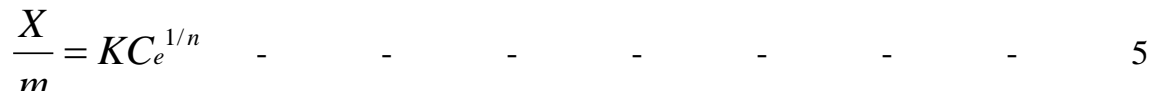

Where: $\mathrm{X}$ is the mass of metal ion adsorbed $(\mathrm{mg}), \mathrm{m}$ is the mass of biomass used $(\mathrm{g}), \mathrm{C}_{\mathrm{e}}$ is the concentration of metal ion at equilibrium, $\mathrm{n}$ is the adsorption intensity and $\mathrm{K}$ is the adsorption constant.

The linear form of equation 5 takes the form (eqn 6)

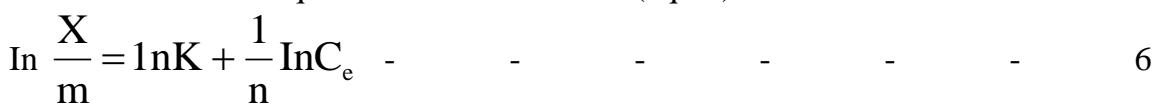

A plot of $1 \mathrm{n} \frac{\mathrm{X}}{\mathrm{m}}$ against $1 \mathrm{nC}_{\mathrm{e}}$, will give a straight line which will confirm the Freudlich Isotherm.

\section{Results and Discussion}

The data in table -1 gives some physical characteristics of the almond tree leaves biomass.

Table - 1: Some physical characteristics of the biomass

\begin{tabular}{|l|l|}
\hline Parameters & Values \\
\hline Apparent density, g/cm & $1.17 \pm 0.06$ \\
\hline Porosity \% & $43.3 \pm 0.08$ \\
\hline Pore volume, $\mathrm{cm}^{3} / \mathrm{g}$ & 0.79 \\
\hline Ash content, \% & $12.3 \pm 0.11$ \\
\hline
\end{tabular}

These characteristics play some important role in the adsorption process of metal ions onto the biomass. The low value of the apparent density $\left(1.17 \pm 0.06, \mathrm{~g} / \mathrm{cm}^{3}\right)$ is an indication of the ease of suspension of the biomass in aqueous solution, which is an essential factor in the interaction between metal ion in solution and a coagulation ligand. Apparent density closer to unity indicates higher contact between sorbate and sorbent. The porosity and pore volume are important factor in characterizing the macrostructure properties of the biomass. The porosity and pore volume of the almond tree leaves biomass are $43.3 \pm 0.08 \%$ and $0.79 \mathrm{~cm}^{3} / \mathrm{g}$ of the biomass respectively.

\section{Effect of $\mathbf{p H}$}

Most plant materials are made up of complex organic residues such as lignin and cellulose that contain several types of polar functional groups. These groups can be involved in chemical bonding and may be responsible for the typical cation-exchange characteristics of most biomaterials.

The $\mathrm{pH}$ of the aqueous medium affects the surface charge of the adsorbent, the degree of ionization, and the species of the adsorbate[7]. 
The $\mathrm{pH}$ dependence data for the sorption of the two metals under investigation are presented on table 2 and Figure 1.

Table-2: The $\mathrm{pH}$ dependent data for sorption of $\mathrm{Al}(\mathrm{III})$ and $\mathrm{Cr}(\mathrm{VI})$

\begin{tabular}{|l|l|l|}
\hline $\mathrm{pH}$ & $\mathrm{Al}^{3+}$ & $\mathrm{Cr}^{6+}$ \\
\hline 2 & 0.081 & 0.083 \\
\hline 4 & 0.086 & 0.076 \\
\hline 6 & 0.071 & 0.063 \\
\hline 8 & 0.063 & 0.059 \\
\hline
\end{tabular}

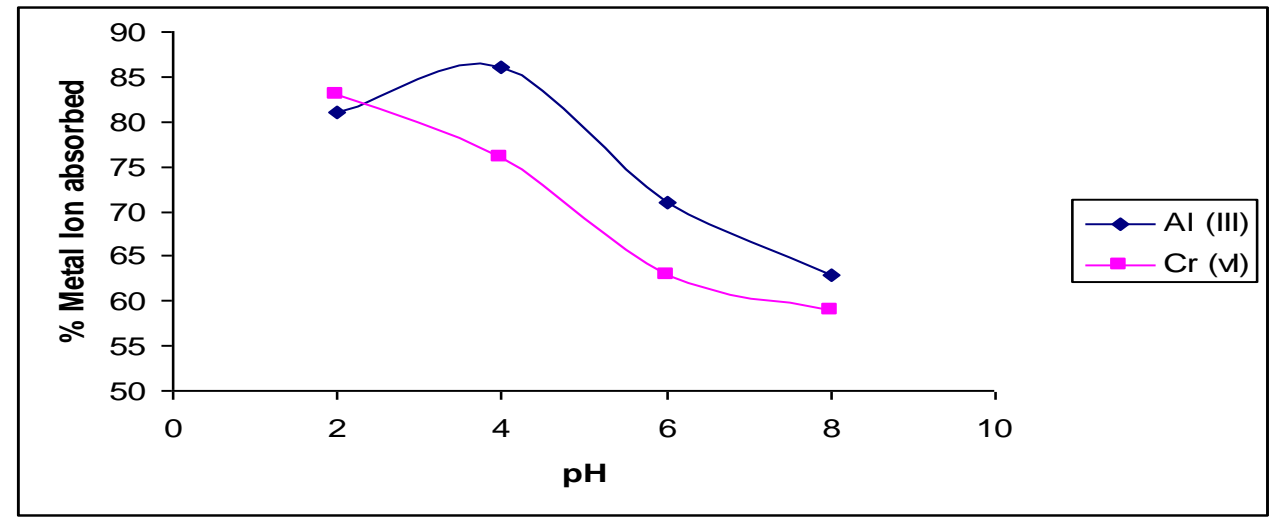

Figure -1: Graphical representation of the $\mathrm{pH}$ dependent data for sorption of $\mathrm{Al}(\mathrm{III})$ and $\mathrm{Cr}(\mathrm{VI})$

The data revealed that, at $\mathrm{pH} 2.0$, there was significant removal of the metal ions by the almond tree waste biomass; $85.5 \%$ for $\mathrm{Al}^{3+}$ and $82.6 \%$ for $\mathrm{Cr}^{6+}$. However, when the $\mathrm{pH}$ was raised to 4.0, there was a large increase in the amount of metal ion removed. At $\mathrm{pH} 4.0$, the biomass removed $85.5 \% \mathrm{Al}^{3+}$ and $76.1 \mathrm{Cr}^{6+}$. $\mathrm{Above}^{-}$ $\mathrm{pH} 4.0$, a gradual decrease in the amount of metal ions removed by the almond tree waste biomass was observed.

A close look at the metal ions investigated showed that $\mathrm{pH} 2$ favours $\mathrm{Cr}^{6+}$ removal with a percentage of up to $82.6 \%$ while $\mathrm{pH} 4$ favours $\mathrm{Al}^{3+}$ (figure - 1).

The overall trend observed in the $\mathrm{pH}$-dependent sorption behaviour suggests that metal uptake occurs through ion-exchange. Our results, thus, indicate that binding follows an ion-exchange mechanism that involves electrostatic interaction between the negatively charged groups in the walls of the biomass and the metallic cations. At low $\mathrm{pH}$, the surface of the adsorbent would closely be associated with hydroxonium ions $\left(\mathrm{H}_{3} \mathrm{O}^{+}\right)$that hinder the access of the metal ions to the surface functional groups, consequently decreasing the percentage of ion removal at low $\mathrm{pH}[5]$.

Surface of the adsorbent, would be closely associated with hydroxonium ions $\left(\mathrm{H}_{3} \mathrm{O}^{+}\right)$which hinder the access of the metal ions to the surface functional groups. Consequently, the percentage of metal ion removal may decrease at low $\mathrm{pH}$.

\section{Sorption Equilibrium}

The applicability of sorption processes as a unit operation can be evaluated using isotherm models. The equilibrium sorption data obtained were analysed in terms of the Langmuir \& Freundlich equations. As shown on table 3 . And the plots are presented on figure 2 .

Table - 3: The values of experimental results as analysed in terms of Langmuir and Fruedlich isotherms

\begin{tabular}{|c|c|c|c|c|c|c|}
\hline \multirow[t]{2}{*}{ Metal ions } & \multicolumn{3}{|l|}{ Langmuir } & \multicolumn{3}{|l|}{ Fruedlich } \\
\hline & KL & $\mathrm{Xm}$ & R2 & $\mathrm{KF}$ & $1 / \mathrm{n}$ & $\mathrm{R} 2$ \\
\hline A1III & $2.37 \times 10^{-2}$ & 36.25 & 0.94 & $1.45 \times 10^{-2}$ & 1.14 & 0.98 \\
\hline CrVI & $1.51 \times 10^{-1}$ & 17.47 & 0.91 & $7.5 \times 10^{-3}$ & 0.97 & 0.95 \\
\hline
\end{tabular}




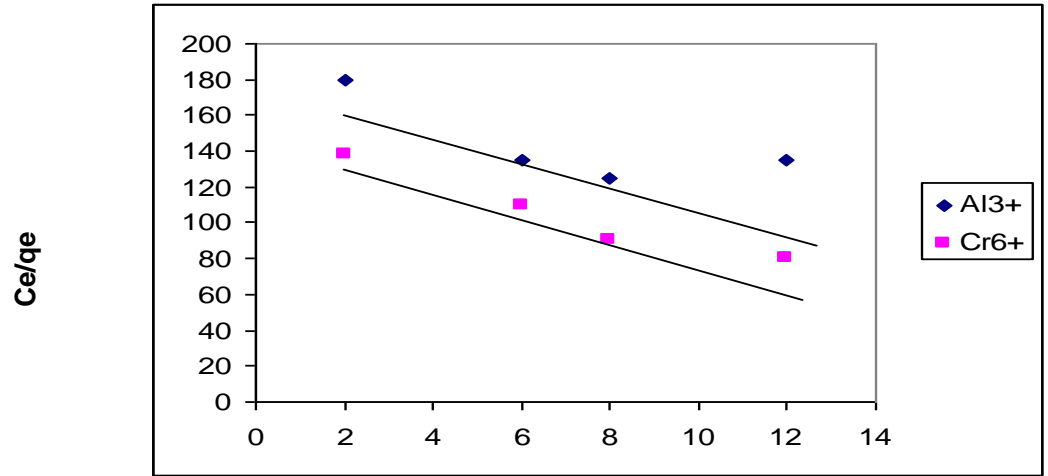

Figure - 2: Graphical representation of the analytical results in terms of Langmuir and Fruedlich isotherms.

The data linearised to fit the Langmuir equation and presents the constants derived by regression analysis for the equation. A comparison of the Langmuir sorption capacity at various initial $\mathrm{pH}$ was made by plotting $\mathrm{q}_{\max }(\mathrm{mg} / \mathrm{g})$ against $\mathrm{pH}_{\mathrm{in}}$. The results confirmed that at $\mathrm{pH} 2$ and 4 , the sorption of $\mathrm{Al}^{3+}$ and $\mathrm{Cr}^{6+} \mathrm{on}$ Terminalia catappa L. biomass was much less than at pH 6 and above, indicating that the Terminalia catappa L. biomass was much less effective sorbent at lower $\mathrm{pH}$ values. Hence, lowering the $\mathrm{pH}$ may aid the regeneration and recycling of spent biomass. The $\mathrm{R}^{2}$ values suggested that the Langmuir isotherm provides a good model of the sorption system. The sorption coefficient, $\mathrm{K}_{\mathrm{L}}$, which is related to the apparent energy of sorption, was greater for $\mathrm{Al}^{3+}$ than for $\mathrm{Cr}^{6+}$ at all $\mathrm{pH}_{\mathrm{in}}$. The high values of $\mathrm{K}_{\mathrm{L}}$ for $\mathrm{Al}^{3+}$ and $\mathrm{Cr}^{6+}$ at $\mathrm{pH} 2$ and 4 respectively, indicate that the energy sorption is more favourable at these $\mathrm{pH}$ maxima than other $\mathrm{pH}$ values.

The linear Freundlich isotherm plots for the sorption of the two metals $\left(\mathrm{Al}^{3+}\right.$ and $\mathrm{Cr}^{6+}$ ) onto the Terminalia catappa L. biomass are presented on figure 3.

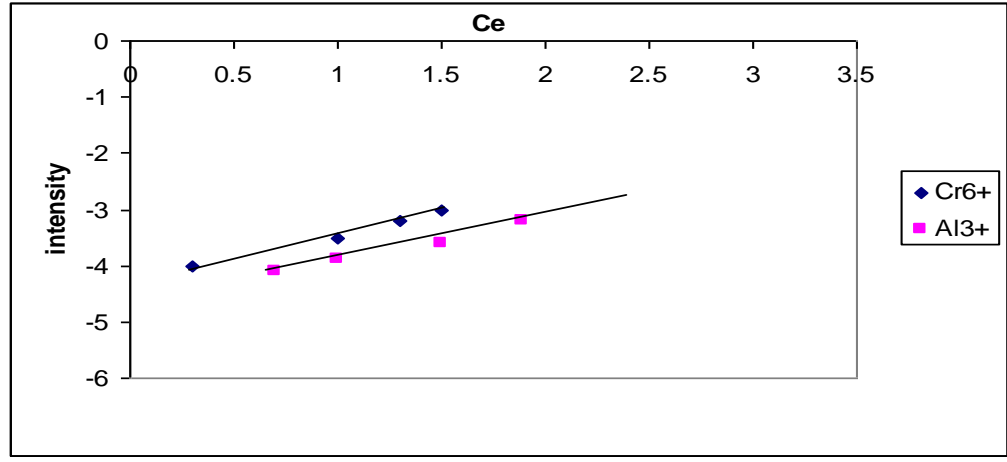

Residual Cone, mg/l

Figure-3: Graphical representation of the equilibrium metal ion concentrations against intensity.

Examination of the plot suggests that the Freundlich isotherm is also an appropriate model for the sorption study of $\mathrm{Al}^{3+}$ and $\mathrm{Cr}^{6+}$.

Values of $\mathrm{I} / \mathrm{n}$ for $\mathrm{Al}^{3+}$ and $\mathrm{Cr}^{6+}$ were found to be less than unity at all $\mathrm{pH}$ respectively, indicating that significant sorption could take place at these initial $\mathrm{pH}$ values. Confirmation of the $\mathrm{pH}_{\max }$ was made by plotting the Freundlich equation parameter, $\mathrm{I} / \mathrm{n}$, which is a measure of the sorption intensity against $\mathrm{pH}_{\mathrm{in}}$. The $\mathrm{plot}$ further confirmed that, the $\mathrm{pH}$ maxima for the sorption of $\mathrm{Al}^{3+}$ and $\mathrm{Cr}^{6+}$ onto Terminalia catappa L. biomass are 2.0 and 4.0 respectively. Based on the coefficient of determination $\left(\mathrm{R}^{2}\right)$ values, the linear form of the Freundlich isotherm appears to produce a reasonable model for the sorption of the two metals, with $\mathrm{Al}^{3+}$ fitting the data better than $\mathrm{Cr}^{6+}$. The $\mathrm{K}$-values suggest that $\mathrm{Al}^{3+}$ has greater sorption tendency towards the Terminalia catappa $\mathrm{L}$. biomass in neutral solutions. However, for $\mathrm{Cr}^{6+}$ the greater affinity towards active groups on the biomaterials was observed at $\mathrm{pH} 4.0$.

\section{Conclusion,}

The data has shown that, the sorption process of $\mathrm{Al}^{3+}$ and $\mathrm{Cr}^{6+}$ ions on to Terminalia catappa $\mathrm{L}$. biomass is feasible and spontaneous in nature. The metal ions binding capacity of the biomass was shown as a function of initial $\mathrm{pH}$ of the aqueous solution. The equilibrium data fitted the Langmuir and Freundhich isotherms very well. The two models confirmed that maximum sorption capacity onto the biomass occurred at $\mathrm{pH} 2.0$ for $\mathrm{Al}^{3+}$ and $\mathrm{pH} 4.0$ for $\mathrm{Cr}^{6+}$. Thus efficient removal of the two metal ions in an effluent using Terminalia 
catappa L. biomass may require $\mathrm{pH}$ adjustment between 4.0 and 2.0. The equilibrium sorption of the two metal ions at their $\mathrm{PH}_{\max }$ was determined from the Langmuir equation and found to be $85.50 \mathrm{mg} / \mathrm{g}$ and $82.60 \mathrm{mg} / \mathrm{g}$ for $\mathrm{Al}^{3+}$ and $\mathrm{Cr}^{6+}$ respectively. The data showed that, Terminalia catappa L. is a successful biosorbent for treating heavy metal contaminated wastewater and may serve as an alternative adsorbent to conventional means. Hence, not only is Terminalia catappa L. readily available, it also has the potential for metal removal and recovery from contaminated waters. This process will be environment friendly and convert the non-useful plant into an economic crop for local farmers. It may also provide an affordable technology for small and medium-scale industries. The $\mathrm{pH}$ study is particularly important for determining the ligands that may be involved in the reaction for optimization in the design of sorption process units.

\section{References}

[1]. Alloway, B. J. Heavy metals in soils. Blackie and Sons Publishers, Glasgow. $\quad 2^{\text {nd }}$ Endition, $1990,158$.

[2]. Perkins, F. J. In: Biology of Plant liter Decomposition. Dickson, C. H. and Pugheds GTF (ed) Academic Press, London, $1974,118$.

[3]. Vinod, V.P. and Antrudhan, T.S. Sorption of Tanic acid on zirconium pillared clay. J. Chem. Technol. Biotechnol, 2001, 77, 92101.

[4]. Quek, S.Y.; Wase, D.A.J. and Forster, C.F. The use of Sago waste for the sorption of lead and copper. Water Res, 1998, 24, (3), $251-256$.

[5]. Abia, A.A.; Horsfall, M. Jnr. and Didi, O. The use of chemically modified and unmodified cassava waste for the removal of Cd, Cu and $\mathrm{Zn}$ ions from aqueous solution. Biores Technol, 2003, 90, (3), 345-348.

[6]. Low, KS., Lee, C.K. and Leo, A.C. Removal of metals from electroplating wastes using banana pith. Biores Technol, 1995, 51 (23), 227-231.

[7]. Gardea-Torresdey, J.L.; Gonzalez, J.H.; Tiemann, K.J.; Rodriguez, O. and Gamez, G. Phytoflltration of hazardous cadmium, chromium, lead and zinc ions by biornass of Medicago sativa (Alfalfa). J. Hazard Mat, 1998, 57 (1-3) 29-39.

[8]. Horsfall, M. Jnr and Abia, A.A. Sorption of $\mathrm{Cd}(\mathrm{II})$ and $\mathrm{Zn}$ (II) ions from aqueous solutions by cassava waste biomass (Manihot sculenla Cranz). Water Res, 2003, 37, (20), 4913-4923

[9]. Ho, Y.S.; John Wase, D.A. and Forster, C.F. Batch nickel removal from aqueous solution by Spagnum Moss Peat. Water Res, 1995, 29, (5), 1327-1332 